\title{
DESIREÉ LJUNGCRANTZ
}

\section{En skev figuration}

\author{
Skrubbsåret som poetiskt akademiskt skrivande
}

\section{SAMMANFATTNING}

Artikeln utforskar och beskriver poetiskt akademisk skrivande. Utforskandet sker med hjälp av feministiska figurationer - särskilt den av skrubbsåret kopplat till hiv - som flätar samman empiri, teorier, normkritiska analyser och levda erfarenheter. Trots att det finns överlappningar mellan det poetiska akademiska skrivandet och akademiskt kreativt skrivande innebär det poetiska akademiska skrivandet att ta kreativiteten ett ytterligare steg. Poetiskt akademiskt skrivande bygger på rytm, associationer och metaforer som möjliggör födesskrivande och skapar ett extra lager i den akademiska texten - både för skribenten och läsaren. Poetiskt akademiskt skrivande kan öppna ett utrymme för läsarens affekter, känslor och kroppsliga förnimmelser i relation till texten. Poetiskt akademiska texter kan också möjliggöra ett möte mellan texten och läsarens situerade kunskap, erfarenheter, kropp och känslor. Artikeln utforskar även skev som begrepp och möjligheten att göra de feministiska figurationerna skeva för att på så vis inkludera erfarenheter, händelser och fenomen som ännu inte är kända för akademiska feminister.

Nyckelord: poetiskt akademiskt skrivande, feministisk figuration, skev, levda erfarenheter, hiv, skrubbsår

När jag var åtta år ramlade jag på cykeln. Skinnet skavdes av. Glittrande småstenar i mitt blod. Svidande smärta, fick mig att skaka. Men jag var inte tillräckligt skadad för att få stöna. Det förstod jag. Som jag stönade.

"Gör rent såret. Rör inte skrubbsåret. Klia inte sårskorpan!" sa de vuxna till mig. 
"Det kommer att läka!" sa de vuxna till mig.

"Cykla försiktigare! Trampa inte så fort! Sakta ner!" sa de vuxna till mig.

Jag gömde skrubbsåret under min kjol och mina byxor. På kvällarna kliade jag på sårskorpan. Jag somnade med blod under naglarna och rosiga kinder.

När jag var femton år menstruerade jag för första gången. Det var sent. Jag var sen. Det droppade ur mig, som ett sår inuti. Rostfärgat blod i mina trosor och på lakanen. Brännande smärta. Gjorde mig yr. Men jag var inte tillräckligt skadad för att få stöna. Det förstod jag. Som jag stönade.

"Du kan känna smärta men det är helt normalt", sa de vuxna till mig.

"Grattis", sa de vuxna till mig.

"Menstruation är ett tecken på att du är kvinna. Nu kan du bli gravid. Använd kondom när du har sex i framtiden", sa de vuxna till mig.

"Du luktar", sa mina klasskamrater till mig.

Jag kapslade in min menstruation. Bindor och tamponger hölls i mörkret i små plastpåsar. Jag gömde dem väl och sprejade parfym över hela mig. På kvällarna rörde jag vid mig själv. Jag somnade med blod under naglarna och rosiga kinder.

När jag var arton år sa läkaren att jag hade hiv. Nivåer av antikroppar, virus och $\mathrm{CD}_{4}$-celler. Sjunkande och ökande. Rörde sig runt, band sig, integrerade, översatte, samlades, spirade. Virusets livscykel och min. Virvlande röda blodkroppar.

Existentiell smärta. Fick mig att krympa. Men jag var inte tillräckligt skadad för att få stöna. Det förstod jag. Som jag försökte att inte stöna.

"Avslöja inte detta för någon som du inte litar på", sa infektionsläkaren till mig.

"Ska du få aids och dö snart?" frågade de vuxna mig.

"Tänk om jag smittar någon", undrade jag själv.

Jag gömde sjukdomen under ett leende. På kvällarna grät jag. Jag kliade på sårskorpan. Jag rörde vid skrubbsåret. Föreställde mig hur viruset flöt fram i mig. Jag somnade med blod under naglarna och rosiga kinder. (Ljungcrantz 2019, I4-I5) 
SYFTET MED DEN här texten är att utforska det poetiska akademiska skrivandet genom feministiska figurationer i allmänhet och skrubbsåret i synnerhet. De feministiska figurationerna knyter samman det empiriska med teoretiska begrepp och en samhälls- och normkritisk analys, samtidigt som de kan synliggöra levda erfarenheter och kroppsligheter. De feministiska figurationerna visar på skrivandets och tänkandets kreativa och snåriga processer och positivismens kliniska omöjligheter, där forskaren alltid medskapar resultatet.

Det poetiska akademiska skrivandet är ett hantverk med olika beståndsdelar som skiljer sig från det kreativa akademiska skrivandet. Att använda poesin är att gå ett steg längre. Det handlar om associationer, rytm, bilder och om att öppna upp mellanrum för läsarens tolkningar, erfarenheter, känslor och kroppar. I den här artikeln beskriver och försöker jag åskådliggöra det poetiska akademiska skrivandets förtjänster och fallgropar.

Artikeln är uppdelad i nio avsnitt. Det första avsnittet fokuserar på forskningsprocessen. I det andra avsnittet berör jag skrubbsåret. Vad en feministisk figuration kan vara utforskar jag i det tredje avsnittet. Det fjärde avsnittet handlar om det queera och det skeva och det femte beskriver hur skrubbsåret kan vara en skev figuration. Det kreativa akademiska skrivandet och det poetiska akademiska skrivandet utgör fokus i det sjätte och sjunde avsnittet, vilka följs av det åttonde avsnittet om den poetiska tillblivelsen. Artikeln avslutas med ett recept för den som vill skapa sin egen figuration.

\section{Att försöka hitta några sammanhållande rottrådar i rhizomerna}

Lakritssmaken och dess salmiakdoft vätskade sig i svalget, det stretade i halsmandlarna. Utöver stensötan var jordsmaken bedövande endimensionell. Myllan täckte halsen och fötterna. Fötterna var nakna, såriga efter stjälkarna från ormbunkarna, de som först hade kittlat henne mellan tårna, fram och tillbaka mellan stortårna, hennes köttiga fots tummetott, slickepott, långeman, gullebrand och lilla vickevire, fram och tillbaka, snabbare och snabbare for de fram så att de små, spetsigt avlånga bladen flög runt henne, bildade en cirkel i mötet mellan ljusgrönt 
och smaragd. De rundade stjälkarna allt plattare, allt trådigare, som ett knippe hår ryckt från huvudet, men inte lika mjukt som hennes, snarare som en gitarrsträng. Hon spelade mellan tårna och huden sjöng så att blodet droppade. Nu låg fötterna under jord. Över benen, höfterna, magen och armarna vilade vågig sidenmossa, fuktig och varm av solen. (Ljungcrantz 2019, 23)

Att befinna sig mitt i en forskningsprocess kan upplevas som att vara nergrävd bland ormbunkar, så djupt att det knappt går att se himlen, och försöka gräva och rota efter några sammanhållande rottrådar i dessa nätverk av rötter - rhizom - där det är närmast omöjligt att avgöra vilka rottrådar som är viktigast eller om någon kom före en annan eftersom systemet helt verkar sakna mönster (vilket inspirerade Deleuze och Guattari 1987 i utvecklandet av det teoretiska begreppet rhizom). Den process jag beskriver ovan ägde rum under min doktorandtid som slutade med en disputation våren 2017 .

Jag sitter på golvet i lägenheten där jag bor. Jag sorterar materialet som jag har samlat in under några år. Det består av skönlitteratur om att leva med hiv, tidigare forskning om hiv främst i Sverige och i en nordamerikansk kontext, det är riktlinjer för infektionsläkare och för patienter som har en positiv hiv-diagnos, det är smittskyddslagen, myndighetsrapporter och artiklar i media (från åren 2005-2014). Tidningsartiklarna består av tre tjocka buntar om cirka roo sidor per bunt (ursäkta miljön och det är uppenbart att jag inte använde mig av dataanalysprogram).

Buntarna blir tunnare framför mig när jag sittandes på golvet läser igenom sidorna. De väller över mig: orden jag läser, ord formade av bokstäver förstås, meningar och stycken fulla av betydelser. Vissa ord och meningar gnager sig fast och letar sig in under huden. Dessa ord är kletiga, eller klibbiga, för att tala med Sara Ahmeds (2004, 60, 90-9r) "sticky concepts". De orden är kategoriserande, fasthållande och negativa: "hiv-infekterad" och "hiv-smittad". Jag minns ännu den så kallade andemeningen, som jag tolkade och upplevde den: åsikterna om att personer med hiv inte borde få ha sex, idéerna om att alla som har hiv är kriminel- 
la, att de som fått hiv har sig själva att skylla och inte förtjänar förståelse. Dessa uttalanden fick min kropp att värka. Idag blir jag mest lite irriterad och har distanserat mig, men det tog tid, och det lever kvar i mig.

Jag läste internationell och svensk forskning om hiv och såg en distans och ett objektifierande "av de hiv-positiva" som störde mig, särskilt när det stigmatiserande begreppet "hiv-smittade" användes.

Jag läste om svenska folkets kunskaper om och attityder till hiv och personer med hiv i rapporten Hiv i Sverige (Smittskyddsinstitutet 2013). En femtedel ansåg att personer med hiv inte borde få ha ett aktivt sexliv. En del kände empiriskt ogrundad rädsla för att få hiv på vardagliga sätt: genom myggor, kyssar, toaletter.

Jag såg Torka aldrig tårar utan handskar (Gardell 2012) och visst grät jag, fann det fruktansvärt, men jag var också irriterad över hur media så lätt kunde fokusera på dåtiden, men nästan aldrig talade om hiv idag.

Med Musikhjälpen i Sveriges Radio under december 2015, som handlade om hiv och aids, kom en markering av att dessa frågor är relevanta även idag, även om fokus låg på det internationella perspektivet (vilket är rimligt med tanke på de ojämlika livsvillkor som blir särskilt tydliga i relation till exempelvis hiv). Nutiden och Sverige befann sig fortfarande på armlängds avstånd. Därefter har informationskravet justerats (Folkhälsomyndigheten \& RAV 20I4, 20I9), kondomkravet kunnat tas bort (Smittskyddsläkarföreningen 2019) och det har uppstått en internationell rörelse kring $\mathrm{U}=\mathrm{U}$, det vill säga omätbar är lika med oöverföringsbar, som även refereras till som smittfri hiv. Min avhandling om hiv i en samtida kontext skulle med andra ord kunna betraktas som ett stycke samtidshistoria, om det nu var så att samhällets kunskaper om hiv baserade sig på adekvat forskning. Tillbaka till dået och avhandlingens material.

Jag hörde intervjudeltagarnas ord öga mot öga, såg deras kroppsspråk, fick deras förtroenden och lyssnade på deras berättelser, och så igen och igen genom inspelningarna medan jag transkriberade, skrev ner deras ord och pauser, för att fånga delar av deras förmedlade erfarenheter: deras vardag, glädjeämnen, deras sorger, rädslor, ensamhet, skam. Vår gemensamma och högst individuella skam. Det tar tid. 
Jag doftar frän svett, känner mig nedbruten med stelnade muskler, och det fortsätter. Lidandet är inte vackert, vill jag påstå, men poesin om lidandet kan vara det. Det finns många ramar inom det akademiska skrivandet och jag behövde någonting annat för att fånga det fenomen som jag studerade. Genom poesins associationer, rytm, bilder, nyanser och friheten från striktare ramar uppstod flödet.

Jag doftar frän svett, känner mig nedbruten med stelnade muskler, och det fortsätter. Jag tuggade i mig allt material, inspirerad av Mia Eriksson $(2016,40)$ som skriver att det går att ta in det krävande forskningsfenomenet i kroppen och spotta ut det. I tuggandet gav vissa ord och delar starkare (bi)smak än andra, och det höll på att fastna där, men det poetiska i det akademiska skrivandet gav mig en kittlande skjuts, så att jag kunde spotta ur mig text. Skrubbsåret blev ett slags lemonad av sura citroner.

Jag doftar frän svett, känner mig nedbruten med stelnade muskler, men efter en tid hittar jag spår av stolthet och ilska i berättelserna och det gör att även stoltheten och ilskan hos mig växer. Genom dessa extroverta känslor lättar skammen bit för bit, år för år.

\section{Skrubbsåret}

När jag snubblade på en trottoarkant och ramlade rakt ner i vasst grus, ställde jag mig hastigt upp och såg mig omkring. "Såg någon mig?" En okänd person som gick bakom mig frågade: "Hur gick det?" "Bra, bra, bara bra, ingen fara", sa jag och log. Men vad ont det gjorde. Huden var bortskrubbad och blod sipprade ut. Det sved och jag försökte le bort grimasen och bete mig "som en vuxen". Så klantigt att ramla. Jag får skylla mig själv. Till skillnad från när jag var ungefär tio år gammal så är blodet i mitt sår nu smittsamt. Det har lagar kring sig, det mäts och övervakas för att skydda mig och andra. Min första tanke om jag gör illa mig är hur jag ska ta bort blodet. Jag fantiserar om och förbereder mig ibland i tanken på hur jag skulle bete mig om jag gjorde mig ordentligt illa, om blodet sprutade: vad skulle jag stoppa blodet med? Min tröja? En handduk? Vad skulle jag säga, skrika? ”Kom inte nära!” Var någonstans skulle det ske - bland folk som vet om hiv? Skulle de som vet fort- 
sätta att hjälpa mig ifall jag skadade mig? Skulle de vara rädda för det/ blodet/viruset/mig? Det vill jag undvika att få reda på. (Ljungcrantz 2017, 62)

Skrubbsåret fångar ett blivande genom ögonblicksbilder i det ständiga blivandets processer och dess flöde, flow (Delueze \& Guattari i987). Skrubbsåret är en rytm, det är bilder, associationer, upplevelser, känslor, kroppsligheter, möten.

Skrubbsår beskrivs av Vårdguiden på följande sätt: "När du ramlar eller glider mot något kan det yttre hudlagret skavas av. Då blir det ett skrubbsår. Det är viktigt att rengöra såret ordentligt eftersom smuts och skräp som finns kvar i såret kan orsaka en infektion” (Vårdguiden 202I). Enligt Svenska Akademins ordlista (SAOL) är ett skrubbsår ett "ytligt sår i huden som uppkommit genom skrapning mot ngt grovt" (Svenska Akademien 2020). Det blir relevant att inte bara rikta blicken mot den som får skrubbsår utan också mot det som tillfogar skrubbsåret: det eller den som skrubbar. Att skrubba innebär att:

Under hårt tryck (med handen 1. händerna) gnida (ngn 1. ngt) 1. föra ett (i sht hårt 1. ytligt skrapande 1. skärande) verktyg fram o. åter över (ngn 1. ngt) o. därigm borttaga smuts 1. ojämnheter 1. dyl. från honom resp. det 1. huden resp. ytan 1. borttaga en del av huden osv.; gm hård gnidning 1 . friktion åstadkomma en 1. flera rispor 1. skråmor 1. avnötta ställen 1. hål o. d. i huden resp. ytan på (ngn 1. ngt); äv. dels med saksubj., dels utan obj.; äv. med obj. betecknande på så sätt åstadkommet hål o. dyl. 1. det som på så sätt avlägsnas. (Svenska Akademien 2020)

Det är i mötet med samhället som skrubbandet uppstår. I mötet med samhället skrubbas huden hos den som avviker från det normativa, i det här fallet hiv-negativa. Det upplevs på gruppnivå: ett hårt tryck, ett gnidande; ojämnheter tas bort, skråmor tillfogas. I intervjustudier finns det alltid kött och blod som genom det konventionella akademiska skrivandet riskerar att försvinna: rationaliseras och steriliseras och tvättas bort. 
Skrubbsåret kan appliceras på andra fenomen och erfarenheter än hiv. Även om kopplingen mellan skrubbsåret och det hiv-positiva blodet laddar figurationen, kan skrubbsåret användas som figuration också för andra levda erfarenheter i form av trauman och kollisioner med samhällskroppen. Skrubbsåret som figuration ska kunna förstås även utan ett identitetsstyrt subjekt. Det gör figurationen skevare. Det för oss till vad som definierar och konstituerar en feministisk figuration och vilka figurationer av feministisk art som har formats och omformats.

\section{De feministiska figurationerna}

Figuration betyder "användande av figurer; egenskap(en) att vara figurerad; sammanställning (komplex) av figurer" (Svenska Akademien 2020). Figurationen är varken en metafor eller en figur. Den är heller inte bara en bild eller en idé. Figurationen är, som $S A O L$ anger, en komplex sammanställning av figurer.

Den feministiska figurationen har skapats inom feministisk filosofi och teoribildning och den har använts och används inom främst genusvetenskapliga texter. Den feministiska figurationen är rotad i posthumanistisk filosofi och en önskan om att bryta med dikotoma uppdelningar mellan å ena sidan kvinna, å andra sidan man, å ena sidan natur, å andra sidan kultur. Och så vidare och vidare. Den feministiska figurationen handlar om att möjliggöra en mer levbar värld (Haraway 2003). Eller som Nina Lykke förklarar är den feministiska figurationen:

En alternativ - positivt bekraeftende - feministisk subjektivitet, som formuleres i en figurlig gestaltet form. (...) Figurationen skal både forstås som en vision, som subjektet er på vej henimod at realisere, og desuden indebaerer den en kritik af her-og-nu situationen. Den taler til tanke, følelse og krop. (Lykke 2008, 233)

\section{Figurationen som subversiv kraft}

Feministiska figurationer har, liksom Lykke (2008) beskriver ovan, potentialen att tänka om, att möjliggöra andra framtidshorisonter och andra sätt att tänka och leva på. Donna Haraways cyborg beskrivs som 
partiell, ironisk, intim och pervers (I99I, I52): “[...]I want to see if cyborgs can subvert the apocalypse of returning to nuclear dust in the manic compulsion to name the Enemy".

Rosi Braidotti menar att figurationen det nomadiska subjektet är en teoretisk figuration för samtida subjektivitet:

[...] a style of thought that evokes or expresses ways out of the phallocentric vision of the subject. A figuration is a politically informed account of an alternative subjectivity. I feel a real urgency to elaborate alternative accounts, to learn to think differently about the subject, to invent new frameworks, new images, new modes of thought. (Braidotti I994, I3)

Figurationen framstår som en nödvändighet för att kunna förstå världen på nya sätt när tidigare beskrivningar inte räcker till. Innovation kan uppstå, men också nya och andra sätt att forma världen på. Det feministiska i figurationen består av en omformning av samhället och en vidgning av tanken, livet, makten och världen. Figurationen blir ett verktyg för att utforska det som ännu inte är.

\section{Annorlunda figurationer som del av en komplex rhizomatisk värld}

Braidotti (I994, I4) har önskat annorlunda figurationer som är sammanflätade av feministisk teori och praktik. Några feministiska figurationer som den svenska forskningen har skapat, och som kommer att göra oss sällskap i texten, är femme, den kvinnliga grotesken och skeva flickor.

Ulrika Dahl beskriver femme på följande sätt: "För mig är femme ett hoppfullt, posthumanistiskt, somatekniskt hondjur som tillsammans med andra feministiska figurationer gör skillnad" (Dahl 20I I, 22).

Det återkommande är återigen att den feministiska figurationen kan skapa positiv skillnad och ge hopp om en annan möjlig ordning. Anna Lundberg beskriver sin figuration den kvinnliga grotesken så här: 
Hon utgör ett synsätt och en samlingspunkt för teori, gestaltar existerande makthierarkier och njutningar, men kan också ge kropp åt en annan möjlig ordning, tafsa på det otänkbara. Hon tar sig också uttryck i det empiriska materialet. (Lundberg 2008, 45)

Här är den feministiska figurationen, den kvinnliga grotesken, en nod där maktkritik från botten (empirin?), från toppen (teorin?) och från sidan (kropp?) möts. Figurationen är komplex och trilskas, den stör och håller samman.

Figurationen utgår från en komplex värld, där Braidotti genom det nomadiska subjektet, försökte att få syn på en intersektionell, samskapande förståelse av en persons multidimensionalitet:

The nomad is my own figuration of a situated, postmodern, culturally differentiated understanding of the subject in general and of the feminist subject in particular. This subject can also be described as postmodern/ industrial/colonial, depending on one's locations. In so far as axes of differentiation such as class, race, ethnicity, gender, age, and others intersect and interact with each other in the constitution of subjectivity, the notion of nomad refers to the simultaneous occurrence of many of these at once. (Braidotti 1994, I4)

Figurationen tar med andra ord sin utgångpunkt i en überkomplex världsbild, samtidigt som den uppmuntrar till multidimensionella analyser. Vi är alla sammankopplade, lika och väsensskilda. Världen är förgrenad och rhizomatisk såsom Deleuze och Guattari beskriver (I987).

Det rhizomatiska använder Maria Margareta Österholm (2012) när hon beskriver hur de figurationer som skapats i och till hennes avhandling förhåller sig till varandra. Här finns en rytm, en dans, ett gemensamt rörelsemönster, och samtidigt skillnader mellan det som pulserar, rytmen skiftar med huvudperson:

Då det i mitt fall finns flera figurationer tänker jag mig att även de är sammanlänkade rhizomatiskt. Den skeva flickan skulle kunna sägas 
utgöra rhizomets mittpunkt, som de andra figurationerna rör sig utifrån och dit de också återkommer. Och även om jag här talar om henne i singularis har hon ett flertal skepnader, beroende på vilket håll hon betraktas ifrån. (Österholm 20I2, 88)

Det ena ger det andra som ger det tredje som blir till någonting annat, så att det är svårt att skilja ut den första knutpunkten i ormbunkens rhizom. Där kommer det akademiska in, vilket jag återkommer till senare. Där kommer kollektivet in: figurationen står inte ensam, den är en del av andra figurationer.

\section{En flock av feministiska figurationer}

De feministiska figurationerna fungerar många gånger pedagogiskt i gestaltningen av forskningsfenomenet. De bildar ett slags queer figurationsfamilj, som Österholm (20I2) i sin avhandling poängterar i linje med Haraway (199I). Denna queera familj "samlar upp och förkroppsligar möjligheter och faror" (Österholm 20I2, 88), men den kan också vara en vargflock.

Vargflockens individer rör sig bredvid varandra, men separat, och målet är hela flockens överlevnad (Deleuze \& Guattari 1987). Så kan också feministiska figurationer verka kollektivt. Våra figurationer kan fungera queert i sin vägran att helt definieras. Våra figurationer är föränderliga och vi välkomnar nya skavande figurationer till flocken som gör det möjligt att ta sig an nya samhällsproblem. I flocken synliggörs samhällsfenomen som skaver inte bara mot de kroppar som vi redan kan kalla för våra, utan mot de kroppar som ännu inte ingår. Figurationerna riktar känselspröten mot det som skavs, mot personer och varelser och liv som befinner sig på marginalerna och för vilka en rösthöjning framstår som otänkbar, omärkbar eller för riskabel. Det är vår utmaning: att fortsätta att behålla figurationernas skevhet, att välkomna och lämna plats åt nya figurationer och att kollektivt stödja varandra så att det både finns utrymme för skapandet av figurationerna och för det subversiva.

Jag rör mig nu från det feministiska och queera till det skeva och jag gör det i flock tillsammans med den blandade empiri som min forskning 
bygger på. I figurationen är jag både ensam och tillsammans. Det skeva bär med sig det feministiska och det queera, men kanske kan det skeva möjliggöra ytterligare andra tankar och praktiker.

\section{De skeva figurationerna}

Queer som begrepp har använts inom feministisk forskning allt sedan Teresa de Lauretis introducerade queerteori på en konferens i99o (se t.ex. Halperin 2003). Sedan dess har betydelserna av queer skiftat, men oftast befunnit sig i motsats till det heteronormativa och cisnormativa. Queer som identitetsbeteckningen "jag är queer" har också blivit allt vanligare. Jag vill gärna stanna kvar i den queerhet som Judith Butler presenterar: queer som normgranskande av köns- och sexualitetsnormer och som ett begrepp som inte låter sig helt definieras (Butler 1990).

Begreppet queer, ofta översatt med pervers och avvikande, har tagits tillbaka på engelska, medan laddningen i det svenska ordet "pervo" inte har förändrats på samma sätt (se Ambjörnsson 2or6). "Skev", som på svenska betyder snedvriden, förvrängd, förvriden och felaktig, förmedlar liksom queer en känsla av att bli gjord felaktig och förvrängd i relation till samhället, att sticka ut och göras avvikande. Det som är skevt är enligt $S A O L$ något som "inte har normal (rak eller rät) riktning eller inställning” (Svenska Akademien 2020). För att inkludera laddningen i det svenska ordet "queer" men nyansera dess relation till sexualitet används, bland annat i detta specialnummer, ordet "skev." Skev har inom feministisk forskning bland annat utvecklats av Österholm (2OI2) genom begreppet "den skeva flickan". Som Österholm poängterar: "skev på svenska har inte de kopplingar till sexualitet som queer, eller finskans pervo, har. Ordet skev brukar heller inte användas som skällsord, knappt ens som en beteckning på människor” (2012, 55). Vidare kopplar Österholm skevheten till Ahmeds tankar om hur de kroppar som anses avvikande känner av en påtaglighet i mötet med samhället och dess normer. Österholm beskriver hur hon låter "skevordet smälta in mer i texten [...] för att visa att normativiteten läcker och att skevheten kan finnas överallt" (Österholm 20I2, I8). I ett specialnummer av Tidskrift för litteraturvetenskap (2005) med temat skev var syftet att inkludera 
även andra normbrott än heteronormativa. I lambda nordicas nummer om begrepp och teori som lämpar sig för 2020-talet beskrivs det skeva av Hilda Jakobsson:

Skev has connotations of something, which is warped, lop-sided, and crooked in a sense that is hard to define but evokes a chafing, scraping, and galling feeling. Therefore, it can be used for that, which disturbs heteronormativity, regardless of it having to do with LGB, T, or heterosexuality. Accordingly, skev is a useful term for the 2020s. (Jakobsson 2020, I52)

I sin avhandling berättar Jakobsson (2018) hur hon använder begreppet skeva livslinjer med inspiration från Sara Ahmeds (2006) begrepp "straight lines". Jakobssons skeva begrepp har alltså nära släktskap med Signe Bremers (20II) begrepp queera kroppslinjer och Anna Siverskogs (20I6) begrepp queera livslopp och mina egna (Ljungcrantz 20I7) normlinjer - som alla bygger på Ahmeds queera fenomenologi, som ju också inbegriper rasism.

Jakobssons skevhet - närmast en feministisk figuration i sig - och Österholms skeva figurationer rör sig inom den litterära världen och fokuserar på femininitet i relation till sexualitet, kön och ålder. Text och skrivande delar jag med dem, men intervjumaterialet skiljer oss åt. Skrubbsåret rör sig inom och mellan det materiella, litterära, levda och politiska - samt det intersektionella med såväl kön och sexualitet som sjukdom, funktionalitet, etnicitet och klass som "tillkrånglare" i de levda mötena med omvärlden och i analysen av det empiriska materialet.

\section{Ett skrubbsår är alltid skevt}

Ett skrubbsår är sällan rätlinjigt och geometriskt utan oftare oformligt med naggade kanter som innehåller hudflagor, bloddroppar, sand och grus eller det material eller den yta som har orsakat skrubbandet. Skrubbsåret är ett jack i huden, inte tillräckligt djupt för att vara ett öppet sår, men huden har skavts av i mötet med en raspig yta. Samhället är den ytan. Allmänheten är den ytan. Skrubbsåret är alltid skevt 
för att det vittnar om en kollision, en aktivitet där det säkra och trygga har överträtts. Skrubbsåret är ett märke i huden, det är någonting som behöver läka, men processen kommer att göra ont och klia och om såret inte rengörs riskerar stenar och smuts att bindas ihop med det nyare hudlagret eller - ännu troligare - att framkalla en inflammation och ett långsiktigt trauma. Och det kliar. $\mathrm{Oj}$ vad det kliar. Där finns en annan möjlighet: att pilla på sårskorpans kanter med naglarna, att inte bara läka och gå vidare utan att pilla för att minnas det som orsakat det. Akten (pillandet) är både tillfredställande och smärtsam (aj) och lämnar inte samhället orört, men ingen ska säga att det inte är krävande.

Skrubbsåret är skevt för att det visar på ett läkande som kommer att lämna spår. Det går inte bara att gå vidare och glömma. Det kan mycket väl bli ett ärr att bära tills man dör. Ärret kanske inte syns för allmänheten om det kan döljas under kläderna, men det finns där (se Bränström Öhman 2008). Och som Sara Ahmed (2004, 2006) poängterar finns det personer som varken kan eller vill bära på sina trauman inför publik. Andra kan och vill bära sina ärr med stolthet. Därför krävs solidaritet som innebär turtagning i aktivismen, för att man ska orka med att kämpa med sådant som att förändra situationen i samhället för fler än den egna gruppen.

Akademiskt gör figurationen skrubbsår det möjligt att tillföra kött och blod till forskningsprocessen. Om skrubbsåret som figurationen är skev snarare än queer har det potentialen att ge skrubbsåret ett extra lager: den blir buckligare och fulare och kanske både spetsigare och bredare. Skevhet kan låta queer ha sitt eget liv och i stället fungera som en intersektionell tankefigur som inkluderar fler maktanalyser (Jakobsson 20I8, 2020; Österholm 20I2), möjligen av det som vi ännu inte känner till. Här bör det reflekteras över rimligheten i att ett fenomen, en händelse, en person eller en aktivitet beskrivs som skev (i relation till queer, se t.ex. Kulick 2005). Allt lite vardagsbångstyrigt är ju inte queert, men kan det vara skevt? I det skeva får vi inte glömma de subversiva dimensionerna i det queera och i de feministiska figurationerna; om vi gör det står vi med en skevhet så stor och utblandad att maktkritiken har försvunnit. Kontinuerligt måste vi också ställa oss frågor om gränserna 
och (o)rättvisorna: Vem kan hantera att leva med ett skevt skrubbsår? Vem orkar och kan överleva med sådana skrubbsår i sitt vardagliga och akademiska liv?

\section{Kreativt akademiskt skrivande}

Kreativ kommer från det latinska ordet creō, som betyder "att skapa" (NE 202I). I det kreativa skapar vi. Jag menar att det kreativa är en del i de flesta forskningsprocesser: forskning är ett skapande och ett utforskande, men ramarna och rigiditeten skiljer sig åt. Dessutom skiljer sig förväntningarna, ramarna och protokollen åt $\mathrm{i}$ olika typer av skrivande. I det kreativa akademiska skrivandet finns det större utrymme för medskapande av ramarna.

Det akademiska handlar om systematisering, stringens, rigorositet och akribi, om att redogöra för processen, metodiken, användningen av teoretiska begrepp i analysen och om att passera inom systemet och få tummen upp av handledare, dekan, opponenter och betygskommitté. När jag skriver "akademiska" här i texten föreslår Word dessa synonymer: teoretiska, verklighetsfrämmande, abstrakta, vetenskapliga, lärda. Det går att strunta i Words definitioner, men "verklighetsfrämmande" ligger långt ifrån processen att skriva en bok om att leva med hiv. Att skriva nära hiv, i kontrast till all den forskning om hiv och personer som lever med hiv som görs utifrån ett distanserat "de"-perspektiv, var av yttersta vikt för mig. Jag ville skriva som jag forskar: på ett stigmasänkande sätt.

I mitt sökande efter verktyg och metodik för skrivandet mötte jag dialogpartners, bundsförvanter, lärare, texter. Laurel Richardson (2002) viskade om skrivande som ett utforskande, "writing as a method of inquiry" och en del av forskningen. Då förstod jag än mer att den akademiska texten kunde vara en text av kött och blod, att den kunde vara kreativ på ett annat sätt än den oftast var.

\section{Att balansera på gränsen till det acceptabla}

Nina Lykke (2008) tydliggör att figurationen är en blandning av fakta och fiktion. Och jag ser nu att det är här, där idén om den poetiska san- 
ningen och forskningens sanningsanspråk möts, som det skaver: det bildas friktion, det bildas fiktion. Detta skavande skapar också en skevhet: energi engageras och någonting nytt blir till. Fakta presenteras inte bara i diagram och i skrift, citat från intervjuer väljs inte bara ut, analyseras och presenteras, dikten är inte bara en dikt: det blir faktafiktion, det blir gestaltad forskning, det blir lyrisk iscensättning av mänskliga erfarenheter, av kroppar, av lidelser, av känslor. Det blir rörigt och mycket, men det kan samtidigt vara tillräckligt stringent och systematiserat. Och det skaver i sin tur. Det skevar. Och skavandet och det skeva fortsätter: nu är det satt i rullning. Ett ständigt skavande: ett passionerat förhållningssätt, en intim relation till materialet, ett begär efter att gestalta på sätt som känns på liknande sätt som materialet känns, som berättelserna känns. Det är en pågående process i linje med Braidottis (2014) multikomplexa författare och alltets (textens, forskningens, människans et cetera) blivandeprocesser.

Jag fick lära mig - och det blev tydligare i vissa rum - att detta mer kroppsliga, känslomässiga, personliga och poetiska sätt att bedriva akademiskt skrivande och kritisk analys är ett risktagande. Ann Werner och Anna Lundberg (2014) beskriver riskerna som att balansera på det akademiska skrivandets innovativa rand genom att ta Karin Widerbergs bok Kunskapens kön (I995) om kön, ålder och sexualitet som ett exempel. Widerbergs skrivande fick så stark kritik att det påverkade henne som person och forskare på ett icke-konstruktivt sätt under lång tid. Kanske är det i detta som det största risktagandet ligger: att skriva en text som kan bli spridd och hånad? Kanske är det också här den största möjligheten finns: i att skriva en text som vidgar det förväntade med vetskapen om att det fortfarande är gedigen forskning som ligger bakom?

Visst minns jag de som var skeptiska till det kreativa skrivandet i min forskning. De var skeptiska både till att jag tog intervjumaterialet och formade gestalter och karaktärer som fick bli viktiga personer i boken och till figurationen skrubbsår. Mest minns jag dock de läsare, både med och utan akademisk utbildning, som tagit del av avhandlingen och som tackat mig för att boket gått att läsa på olika sätt uti- 
från de egna förutsättningarna och intressena. Ett viktigt argument för att skriva poetiskt och akademiskt är den pedagogiska poängen och att man som forskare har ett pedagogiskt uppdrag att förmedla forskningen till en bredare grupp - kanske till och med till den grupp som berättelserna berör. Häri ligger också det feministiska: en önskan om folkbildning.

I bästa fall resulterar det kreativa akademiska skrivandet i en välskriven akademisk text som gestaltar det som den utforskar och som griper tag och berör och levandegör forskningsresultaten. Hur en akademisk text av detta slag tas emot handlar delvis om mottagarens (o)vana att ta till sig den, om mottagarens disciplinära skolning och förtrogenhet med de konventioner som disciplinen är förknippad med - kort och gott om mottagarens förmåga att se en akademisk text och ett forskningsresultat när hen ser dem. Min hållning är att olika sorters skrivtänkande, genreförhållanden och gestaltningspresentationer av forskningsresultat kompletterar varandra: det är alltid bättre med både och än antingen eller.

För vad är alternativet - att putsa bort känslor och kroppar och ansluta till den upphöjda idén om sanning? Ja, troligen som Bränström Öhman konstaterar, med stöd från både bell hooks och Sara Ahmed:

Att däremot försvara sig genom förnekelse, till exempel genom att som feministisk forskare ansluta sig till ett rationellt kunskapsparadigm, innebär att man tar risken att medverka till legitimerandet av tankens och förnuftets primat och därmed också befästa de föreställningar som, bidrar till att vidmakthålla förtrycksstrukturerna. (Bränström Öhman 2008, I7)

Allt har konsekvenser. Alla har inte möjlighet, vilja eller förmåga att välja. Ibland blir följderna märken på och i ens eget kött. Och kanske är det detta som är det feministiska - att acceptera och förstå olikheter i förutsättningar, utgångspunkter och sätt att verka för förändring. Men som Maud Eduards skrev för snart femton år sedan kräver feministisk vetenskap både motstånd och solidaritet: 
Klimatet mot feministiskt skrivande kommer att bli kyligare [...]. Återstår att vi som skriver feminism inom akademin [...] sanktionerar 'onormal', obekväm och gränsöverskridande forskning. För vem ska legitimera motståndets olika [obehagliga] uttryck, om inte vi? (Eduards 2008, 57)

Det kreativa akademiska skrivandet har potential att förverkliga de kritiska samhällsanalyserna och de akademiska kritiska dialogerna som kan utmana bakomliggande tankemönster (Bränström Öhman 2008; Ahmed 2004). Det skapar en möjlighet, men för att det akademiska skrivandet ska öppna upp för andra sätt att leva och verka på behöver också människor utanför akademin bjudas in till denna skeva process.

Det poetiska är att gå ett steg längre.

Jag återgår till köttet.

Huruvida det skönlitterära skrivandet handlar om gestaltning och genre, medan det akademiska hantverket handlar om någonting helt annat, därom tvista de lärda. Jag väljer att gå ett steg längre och öppnar dörren för det poetiska. Det poetiska är att gå ett steg längre: närmare kroppen, närmare erfarenheten, närmare känslorna, närmare sinnligheten, sårbarheten, "sanningen" och med sanningen menar jag livet.

Det poetiska akademiska skrivandet är att gå ett steg längre.

\section{Poetiskt akademiskt skrivande - estetik, affekt, kropp och mening}

Lyriken tillhör antikens tre teatergenrer: epiken, dramatiken och lyriken. Epiken fokuserar på berättande (epos) i form av romaner, medan dramatiken ska framföras på scen och lyriken är text framförd som sång, ofta ackompanjerad av lyra. Poesin stammar ur lyriken och ordet lyrik används ibland också synonymt med poesi, om texter som styrs av bilder, sinnen och rytm och som ska läsas tyst eller reciteras (Elleström I999). Det finns stråk av fantasifullhet $i$ all fiktion och det finns nivåer av mystik i allt författande, men poesin och poeten är kanske de som oftast associeras med ett kreativt lidande.

Ordet "poesi" härstammar från det grekiska poiēsis av poiéó, som betyder "att göra" (NE 202I). Det poetiska "att göra" är viktigt som 
tillägg till det kreativas "att skapa". Att göra och att skapa. Poesin är kreativ, men det kreativa är inte alltid poesi, än mindre poetiskt. För mig handlar det poetiska akademiska skrivandet om att göra som jag lär. Vi kan kalla det för ett akademiskt aktivistiskt görande, ett slags performativitet á la Judith Butler (1990). Med det menar jag att det fenomen som jag forskar om, exempelvis hiv, har vissa (o)önskade följeslagare såsom skam - som jag behöver ta på allvar i min forskningsprocess och i kunskapsspridningen. Forskningsresultatet behöver spridas på såväl kunskapshöjande som skambefriade sätt. På så vis ligger forskningen nära det som studeras och försöker att inte reproducera de problembilder som forskningen visar. Att skapa utrymme för föreställningar om andra, mer jämlika framtider är som jag konstaterat en del av syftet även med feministiska figurationer.

Poesins beståndsdelar består av ordval och radbrytningar och rytm. I poesin skapas ett konstverk som talar till läsaren på flera nivåer (Kristeva I984). Poesin försöker ta sig in i läsarens kropp med sin rytm, sina bilder, sin symbolism (Kristeva I984). Poesin innehåller inte bara raka budskap, såsom dem den akademiska texten ofta siktar på, utan har sin undertext, sina betydelser mellan raderna, sina stämningar och nyanser. Även i akademisk text kan läsaren göra flera tolkningar, finna undertexter och betydelser mellan raderna - men poesin är uppbyggd på just detta; här ligger det kortet så att säga på bordet. Därigenom menar jag att det poetiska akademiska skrivandet kan fånga komplexa fenomen som studeras.

Hanna Nordenhök (2018) beskriver poesin och det poetiska skrivandet som händelser och relationalitet i "ebb och flod", där praktik, teori och situerade erfarenheter i skrivandet blir explorativa och performativa processer. Alla feministiska figurationer kan vara kreativa, men alla är kanske inte poetiska. Jag menar att de feministiska figurationerna har potential att vara poetiska genom sina komplexa former, noder, undertexter, mellanbetydelser, bildspråk och kroppsliga dimensioner, men de beskrivs inte alltid på ett poetiskt sätt. För dessa feministiska figurationer behöver balansera på gränsen för att tillräckligt väl passa in i den vetenskapliga genren och logiken; det associativa måste behålla 
sin stringens, det metaforiska vara fjättrat vid sin praktik, det känslomässiga vara lagom kliniskt och det kroppsliga tillräckligt abstrakt och analyserbart.

Det poetiska akademiska skrivandet tar Karen Barad (2007) på allra högsta allvar i det partiella utsnittet, "agential cut", som forskaren analyserar genom sina redskap och metoder och sina förgivettaganden. Återigen, detta kort ligger på bordet i det poetiska akademiska skrivandet.

Det poetiska akademiska skrivandet är ett kroppsligt, känslomässigt, aktivistiskt och analytiskt arbete som jag menar går hand $i$ hand med det fenomen som studeras (Richardson 1990, 1993, 1997; Lather \& Smithies 1997; Richardson \& St. Pierre 2005). Särskilt när den personliga kunskapshorisonten, eller den situerade kunskapen som Haraway (I99I) benämner den, berörs. Då kan det brännas, då kan huden skavas, samtidigt som forskaren själv inte kan gömma sig. Men är den poetiska logiken helt väsensskild från den vetenskapliga? När poesins extremer - dess fluffighet respektive knivskarphet - möts, ja. Men som process och slutprodukt? Delvis, men det poetiska akademiska skrivandet, dess forskningsprocess och slutprodukt (text), är just både poetiskt och akademiskt.

Det poetiska erbjuder någonting, om inte mer, så någonting annat: en fingertoppskänsla, som ofta finns även i analyser och tolkningar inom mer konventionella vetenskapliga processer, men som här tar in det mjuka, det som har könats (feminint), det kletiga och klibbiga (känslor och sådant där ni vet) och det födiga (kroppen, dess njutningar, smärtor, vätskor och låsningar). Det poetiska i det poetiska akademiska skrivandet öppnar upp mellanrum för läsaren med dennas tolkningar, erfarenheter, känslor och kroppar. Låt oss nu gå till det poetiska akademiska skrivandets skapandeprocess.

\section{Den poetiska akademiska tillblivelsen}

Jag vill säga det ungefär så här:

Den poetiska tillblivelsen är en process som startar någonstans i din kropp, via nervtrådar i hjärnan, som blir ord, och ordet har flera lager: en känsla, en situation, ett ord, en rytm, en sång, ett ljud, ett fotografi, ett minne, ett sinne. Inget av detta är singulärt. 
En process startar någonstans i din kropp, via nervtrådar i hjärnan, tar sitt sikte och sin rörelse mot någonting: att förstå, att skapa mönster, att kategorisera, att justera, att bygga, att väva samman. Som på pränt blir till.

Skapelsen uppstår via nervtrådar i hjärnan, som tar sitt sikte och sin rörelse från någonting: att fly, att förneka och glömma, en sömnlöshet, en kroppssmärta. Som på pränt blir någonting annat.

Att det poetiska skrivandet står i motsats till annat slags skrivande är kännbart, men motsatsförhållandet reducerar både det ena och det andra. Varken det ena eller det andra går särskilt vackert ur bråket, så jag höjer ett varningens finger inför att uttrycka sig i alltför positiva ordalag om det poetiska akademiska skrivandet med dess genreblandningar och kreativa fiktionsgestaltningar, och i samma andetag önskar jag en ödmjuk hållning i de eventuella försvarstalen för mer konventionell forskningsproduktion. Det poetiska akademiska skrivandet kan bli en otydlig varelse, både vad gäller process, resultat och redovisning. Därmed kan det poetiska akademiska hamna i konflikt med de mer traditionella förväntningarna på och ramarna kring akademiskt hantverk. De poetiska akademiska texterna kan, likt en del övrig poesi, uppfattas som svåra att ta till sig. De bryter mot det förväntade, de påminner om det skeva och queera och det kan ge upphov till oro, missnöje och osäkerhet om hur texten ska förstås och tolkas. Balansen mellan det poetiska och det akademiska är just här: syfte, metodik och tolkningsraster kan presenteras på ett rigoröst sätt även $\mathrm{i}$ det poetiska akademiska skrivandet. Allt skrivande är en process som både har sina ramar och sina öppningar. Vi kan låta dessa mötas på fruktbara sätt.

\section{Ett recept på poetiskt akademiskt skrivande i form av en skev feministisk figuration}

För den som vill skapa en figuration i sitt akademiska skrivande kommer här ett recept:

I. Forska gärna om någonting som är lite för nära ditt privatliv eller någonting som är emotionellt upprörande. 
2. Se gärna till att ditt material är massivt, det vill säga att du inte bara har mycket att ta in, utan för mycket att ta in, göra urval från och att analysera och presentera.

3. Konsumera materialet genom närläsning - läs, läs, läs, det vill säga läsning där du uppmärksammar ordens skiftande innebörder, nyanser, tilltal, värderingar (se t.ex. Lundberg 2008, 39-40). (Om du använder datorprogram för kodning och delar av analysarbetet kommer du inte att bli lika överväldigad. Se detta som en blandmetod om du vill komplettera med eller göra kontrollanalyser genom ett effektivt kodingsprogram.)

4. Känn svallvågorna av materialet skölja över dig.

5. För fältdagbok om allt detta: vad du ser i materialet, materialets teman och underteman, hur du upplever processen och materialet, dina kroppsliga förnimmelser, dina känslor. Det handlar inte om narcissistisk introspektion utan om hur forskningen, materialet och du tillsammans omvandlas, om hur du som forskare skapar din forskning, om hur du som person hanterar processen och om hur du kan vara en människa i en komplicerad analytisk process.

6. Flödesskriv. Välj något ord eller en mening ur din fältdagbok. Det ska vara någonting som du "går igång på", någonting som skaver, någonting som gör dig irriterad eller lustfylld. Skriv det ordet på dator eller papper (du får inte redigera i det här skedet: håll censurvarelsen på avstånd och fortsätt att skriva vad som än väller ur dig). Skriv i fem minuter. (Det kan vara så att du låser dig och att det här inte alls fungerar. Försök i så fall att ha tålamod med dig själv och att prova igen en timme senare, en annan dag, en annan vecka. Och försök att nonchalera censurvarelsen trots att den sitter på din axel).

7. Läs texten och plocka ut de ord och meningar du gillar. Tänk på ditt material, på dina teoretiska begrepp, på dina frågeställningar och skriv en ny text av de ord du valt (tänk på det, ta in det, känn in det: alla utsagor, personer, erfarenheter och händelser, alla drömmar och relationer och samband). 
8. Finns det en figur, en varelse, ett väsen, en gestalt, en känsla, någonting ur flora eller fauna som sticker ut här? Det ska vara någonting som sammanför de olika delarna i det du gör: material, teorier, teman, processen. Det ska vara någonting som kan fungera som en symbol för det arbete du gör - för det akademiska och personliga arbete du bedriver, för det fenomen du (ut)forskar.

9. Ta ordet: sök på dess betydelser, skriv om just det ordet, om hur det har kommit till liv, om vad det symboliserar, om hur det speglas i materialet och teorierna och hur det är användbart för dig.

Io. Du har skapat din figuration (och kan nu använda den som en del i din analysprocess, under metodologiavsnittet i din avhandling, för att överleva ditt avhandlingsarbete; du kan också brodera den på en tavla som kan ge stöd på vägen, eller skriva den på ett papper som du sparar på ditt skrivbord och sedan eldar upp när arbetet är klart). PS glöm inte att beskriva processen bakom figurationens tillblivelse om du ska använda den i din akademiska text DS.

Skrivövningen som handlar om att flödesskriva i receptet ovan har inspirerats av en av Nina Lykkes skrivworkshops, vilken i sin tur inspirerades av Sissel Lie (2014).

Desiré luUngcrantz doktorerade 2019 vid Tema Genus, Linköpings universitet, med avhandlingen Skrubbsår: Berättelser om hur hiv föreställs och erfars $i$ samtida Sverige. År 2020 utkom hennes debutroman Hyperdulia. Desireé skriver, föreläser och arbetar inom området sexuell och reproduktiv hälsa och rättigheter.

\section{REFERENSER}

Ahmed, Sara. 2004. The Cultural Politics of Emotion. New York \& London: Routledge.

-. 2006. Queer Phenomenology: Orientations, Objects, Others. New York \& London: Routledge. 
Ambjörnsson, Fanny. 20r6. Vad är queer? Stockholm: Natur \& kultur.

Barad, Karen. 2007. Meeting the Universe Halfway: Quantum Physics and the Entanglement of Matter and Meaning. Durham \& London: Duke University Press.

Bränström Öhman, Annelie. 2008. "Show some emotion! Om emotionella läckage i akademiska texter och rum." Tidskrift för genusvetenskap, nr 2, 7-31.

Butler, Judith. I990. Gender Trouble: Feminism and The Subversion of Identity. New York \& London: Taylor Francis.

Braidotti, Rosi. 1994. Nomadic Subjects: Embodiment and Sexual Difference in Contemporary Feminist Theory. New York: Columbia University Press.

-. 2014. "Writing as a Nomadic Subject". Comparative Critical Studies nr 2-3, I63-84. Edinburgh University Press.

Bremer, Signe. 20I I. Kroppslinjer: Kön, transsexualism och kropp i berättelser om könskorrigering. Diss. Göteborg \& Stockholm: Makadam förlag.

Dahl, Ulrika. 2or r. "Ytspänningar: Feminismer, femininiteter, femmefigurationer." Tidskrift för genusvetenskap, $\mathrm{nr}$ I, 5-27.

Deleuze, Gilles, \& Guattari, Felix. 1987. A Thousand Plateaus: Capitalism and Schizophrenia. Minneapolis: University of Minnesota Press.

Eduards, Maud. 2008. "Texten, du och jag." Tidskrift för genusvetenskap, nr 2, 54-58.

Elleström, Lars. 1999. Lyrikanalys: En introduktion. Lund: Studentlitteratur.

Eriksson, Mia. 20I6. Berättelser om Breivik: Affektiva läsningar av våld och terrorism. Diss. Göteborg \& Stockholm: Makadam förlag.

Folkhälsomyndigheten \& RAV. 2014. Smittsambet vid behandlad hivinfektion: Kunskapsunderlag från Folkhälsomyndigheten och Referensgruppen för Antiviral terapi. 2. rev. uppl. Solna: Folkhälsomyndigheten.

—. 2019. Smittsambet vid behandlad hivinfektion. Solna: Folkhälsomyndigheten.

Gardell, Jonas. 20I2. Torka aldrig tårar utan handskar [Videoupptagning], regi: Simon Kaijser; producent: Maria Nordenberg. Stockholm: AB Svensk filmindustri.

Jakobsson, Hilda. 20I8. Jag var kvinna: Flickor, kärlek och sexualitet i Agnes von Krusenstjernas tidiga romaner. Diss. Göteborg: Makadam förlag.

-. 2020. "Skev." lambda nordica, nr I, I50-I54.

Halperin, David M. 2003. "The normalization of queer theory.” J Homosex, nr 2-4, 339-343. doi: 10.1300/Jo82v45no2_I7.

Haraway, Donna. 1991. Simians, Cyborgs, and Women: The Reinvention of Nature. London: Free Association Books.

-. 2003. The Haraway Reader. New York: Routledge.

Heggestad, Eva, Maria Karlsson \& Anna Williams. 2005. “Introduktion.” Tidskrift för litteraturvetenskap, $\mathrm{nr}$ 3, 3-6.

Kristeva, Julia. I984. Revolution in Poetic Language. New York: Columbia University Press. Kosofsky Sedgwick, Eve. I990. Epistemology of the Closet. Berkeley: University of California Press. 
Kulick, Don. (red.) 2005. Queersverige. Stockholm: Natur och Kultur.

Lather, Patti \& Chris Smithies. 1997. Troubling the Angels: Women Living with HIV/ AIDS. Boulder: Westview Press.

Lee, Mara. 2014. När Andra skriver: Skrivande som motstånd, ansvar och tid. Diss. Göteborg: Glänta Produktion.

Lie, Sissel. 201 4. "From an Empty Head to a Finished Text: The Writing Process." I Writing Academic Texts Differently: Intersectional Feminist Methodologies and the Playful Art of Writing, redaktör Nina Lykke. London: Routledge.

Ljungcrantz, Desireé. 2017. Skrubbsår: Berättelser om hur hiv föreställs och erfars i samtida Sverige. Diss. Göteborg: Makadam förlag.

—. 2019. Hyperdulia: Roman. Lund: Ekström \& Garay.

Lundberg, Anna. 2008. Allt annat än allvar: Den komiska kvinnliga grotesken i svensk samtida skrattkultur. Diss. Göteborg \& Stockholm: Makadam förlag.

Lundberg, A., Werner, A. 2or4. "Kreativt skrivande och kritiskt tänkande i genusvetenskap." Kreativt skrivande och kritiskt tänkande i genusvetenskap. En skriftserie om genusvetenskap, redaktörer Anna Lundberg och Ann Werner, 9-I6. Göteborg: Nationella sekretariatet för genusforskning.

Lykke, Nina. 2008. Kønsforskning: En guide til feministisk teori, metodologi og skrift. Frederiksberg: Samfundslitteratur.

NE, Nationalencyklopedin. "Poesi." www.ne.se. Hämtad 20 januari, 202 I.

—. "Kreativ." www.ne.se. Hämtad 20 januari, 202 I.

Nordenhök, Hanna. 2018. Det svarta blocket i världen: Läsningar, samtal, transkript. Diss. Göteborg: Göteborgs universitet.

Richardson, Laurel. 1990. Writing Strategies: Reaching Diverse Audiences. Newbury Park: Sage.

-. I993. "Poetics, Dramatics, and Transgressive Validity. The Case of the Skipped Line.” Sociological Quarterly, nr 4, 695-710.

-. I997. Fields of Play: Constructing an Academic Life. New Brunswick: Rutgers University Press.

Richardson, Laurel \& Elizabeth Adams St. Pierre. 2005. "Qualitative Writing: Writing as a Method of Nomadic Inquiry." I The Sage Handbook of Qualitative Research, redaktörer Norman K. Denzin \& Yvonna S. Lincoln, 959-78. Thousand Oaks: Sage.

Rosenberg, Tiina. 2002. Queerfeministisk agenda. Stockholm: Atlas.

Svenska Akademien. 2020. "Figuration". I Svenska Akademiens Ordlista. https://svenska. se/saol/. Hämtad ro juni, 2020.

Svenska Akademien. 2020. "Skrev". I Svenska Akademiens Ordlista. https://svenska.se/ saol/. Hämtad ro juni, 2020.

Svenska Akademien. 2020. "Skrubbsår". I Svenska Akademiens Ordlista. https://svenska. se/saol/. Hämtad ro juni, 2020.

Siverskog, Anna. 2016. Queera livslopp: Att leva och åldras som lhbtq-person i en heteronormativ värld. Diss. Linköping: Linköpings universitet. 
Smittskyddsinstitutet. 2013. Hiv i Sverige: Kunskaper, attityder och beteenden hos allmänbeten I987-20II. Solna: Smittskyddsinstitutet.

Smittskyddsläkarföreningen. 20r9. Smittskyddsläkarnas smittskyddsblad. Hiv person med välinställd hivbehandling, patientinformation. https://slf.se/smittskyddslakarforeningen/app/uploads/2org/o7/hiv-pat-medvalinstalld-behandling-I90703-korrekt-titel.pdf. Hämtad ro juni, 2020.

Vårdguiden I 177. 202 I. "Skrubbsår." https://www.i I77.se/olyckor--skador/sar-ochblamarken/skrubbsar/. Hämtad 20 januari, $202 \mathrm{I}$.

Österholm, Maria Margareta. 201 2. Ett ficklaboratorium i valda bitar: Skeva flickor $i$ svenskspråkig prosa från 1980 till 2005. Diss. Uppsala: Uppsala universitet.

\section{ABSTRACT}

The article explores and describes poetic academic writing, through feminist figurations in general, specifically through abrasion as a figuration that knits together empirics, theories, norm-critical analysis and lived experiences of HIV. Although there is an overlap between poetic academic writing and academic creative writing, poetic academic writing takes creativity one step further. The craft is built on rhythm, associations, and metaphors. It creates a possible writing flow, as well as an extra layer, for the researcher/writer, that might be combined on different levels with more conventional and rigorous academic writing and research practices.

As such, poetic academic texts offer a widened space for interpretations by the reader, and encourage affective, emotional, and bodily sensations when digested by the reader. The poetic academic text offers an encounter between the text and the reader's own situated knowledge, position, body and emotions.

The article explores skew (skev) as a concept, making feminist and queer figurations skew, in a way that may prove fruitful in including experiences, situations and phenomena not yet known to academic feminists. 